\title{
Migrating out of Poverty in Zimbabwe
}

\author{
Vupenyu Dzingirai, Eva-Maria Egger, Loren Landau, \\ Julie Litchfield, Patience Mutopo and Kefasi
}

\author{
Nyikahadzoi
}

\section{Working Paper 29}

\section{September 2015}




\section{Acknowledgements}

This working paper is part of the "Migrating out of Poverty" Research Programme. The "Migrating out of Poverty" Research Programme funded by the UK's Department for International Development from 2010-2017, focuses on the relationship between migration and poverty in six regions across Asia, Africa and Europe. The programme is co-ordinated by the University of Sussex.

The authors of this working paper would like to express their sincere gratitude to DFID for providing funding for this regional research and to the RPC management team at the University of Sussex. We would also like to members of the Centre for Applied Social Sciences, University of Zimbabwe, for supporting the fieldwork training and data entry and to member of the African Centre for Migration and Society for comments on early presentations of our preliminary. Special thanks to Mthente Consulting, Cape Town and in particular to Kudakwashe Matongo, for coordinating the preparation of survey instruments, facilitation of training and for overseeing data verification.

The UK Department for International Development (DFID) supports policies, programmes and projects to promote poverty reduction globally. DFID provided funds for this study as part of that goal but the views and opinions expressed are those of the author(s) alone.

(C) 2015 by Dzingarai et al. Short sections of text, not to exceed two paragraphs, may be quoted without explicit permission provided that full credit, including (c) notice, is given to the source. 


\section{Abstract}

This paper present preliminary results from the MOOP household survey conducted in Zimbabwe in 2015. We provide a profile of migrants and of their households and also explore perceptions of the value of migration. Finally we provide an agenda for further research using our data. Two observations are worthy of further research. First is the finding that male migrants send more money home to their families than female migrants, which we suggest is due to differences in job opportunities available to migrant's at their destination (skilled construction for men and domestic work for women). However this finding ignores the value of non-cash remittances, which we intend to explore in future work. We also find that households while generally positive about the value of migration to their living standards, are less positive in the context of international migration. We suggest this reflects recent events in South Africa, not least the devaluation of the Rand and an intensification of xenophobia. 


\section{Executive summary}

This paper provides preliminary observations drawn from the MOOP household survey conducted in Zimbabwe in April/May 2015. This survey completes the set of comparable studies carried out elsewhere by MOOP partners in Ghana, Ethiopia, Bangladesh and Indonesia from 2013 through to 2015. To our knowledge, this is the first study which collects both qualitative and quantitative data in a survey of this size in Zimbabwe, with a sample of both households with migrants and without migrants.

Specifically we provide a profile of Zimbabwean migrants and their households and we report on perceptions held by households in Zimbabwe on whether and how migration is a viable strategy to escape poverty. What we present here is a discussion of preliminary descriptive statistics on a small number of aspects of migration in and from Zimbabwe, with the intention of sharing preliminary observations and the aspiration of raising awareness of the availability of this data set for the wider research community.

We define a migrant as a former member of the household who within the last 10 years has moved away from the village for at least three months for either work or study reasons and is currently away. We distinguish between internal migration and regional (to other southern African countries) and international migration

The majority, $72 \%$, of migrants identified in our sample are male, who generally have been away from home for longer than the female migrants in our sample. Migrants also tend to be quite old: around 32 years old on average, and older than the (adult) non-migrants in our sample. The majority of migrants are sons or daughters of the household head. We observe little difference in household consumption expenditure levels between households of different migration statuses, but recognise that this simple comparison ignores the potential underlying differences in welfare between households which might be correlated with living standards. Remittance behaviour varies between male and female migrants, with men tending to remit more cash than women. This may reflect different work opportunities and pay structures at destination: the most common occupation for men at destination is skilled construction, whereas for women it is domestic service. However, non-cash remittances are 
not explored and it is possible that there are different patterns of cash and non-cash remittances.

We also examine attitudes held by households of the value of migration. Although a slight majority of households report that migration has positive consequences generally for households, there appears to be a negative perception of the benefits of migration among those households who have migrants abroad, in contrast to those whose migrant members remain within the country. As our sample of international migrants are predominantly based in South Africa, we infer this to be related to recent xenophobic attacks and/or the recent devaluation of the South African Rand. 


\section{Introduction}

Migration has long been used as a way for households to seek work, improve their livelihoods and raise their incomes, as well as to escape more extreme situations of persecution, conflict and hunger. While the global migration crises in the Mediterranean and the Indian Ocean currently attract the attention of the international press and national governments, much less is written about the movements of people within their own borders or within their regions to neighbouring countries. The Migrating out of Poverty (MOOP) research consortium aims to redress this imbalance by documenting and analysing internal, regional and international migration patterns, determinants and effects with the objective of investigating the role that migration plays in the strategies of households to escape from, or avoid falling into, poverty.

The study in Zimbabwe is one of a number of comparable studies carried out by MOOP partners in Ghana, Ethiopia, Bangladesh and Indonesia, and this working paper provides preliminary evidence from fieldwork conducted in April and May 2015. Specifically we provide a profile of Zimbabwean migrants and their households and we report on perceptions held by households in Zimbabwe on whether and how migration is a viable strategy to escape poverty. What we present here is a discussion of preliminary descriptive statistics on a small number of aspects of migration in and from Zimbabwe, with the intention of sharing preliminary observations and the aspiration of raising awareness of the availability of this data set for the wider research community.

To our knowledge, this is the first study which collects both qualitative and quantitative data in a survey of this size in Zimbabwe, with a sample of both households with migrants and without, and specifically addressing issues around migration, remittances and poverty. Our preliminary research adds to earlier work on the role of remittances and migration as a poverty reduction strategy by Bracking and Sachikonye (2006), Raftopolous (2011) and Crush and Tavera (2010) and we hope our data will enable further insights to be made on a this complex phenomenon.

\section{A History of Migration in Zimbabwe}


Zimbabwe might be said to have two migration histories, the old and the new, broadly corresponding to the pre and post-independence periods. Old Migration follows the tribal warfare based displacements with roots in South Africa and appears to start with colonialism. In the early 1890s and early 1900s, pacified Africans migrated to farms, and new towns of Bulawayo, Salisbury, Gwello and Fort Victoria and their surrounding mines and farms. There are conflicting views about the causes of this migration. Some scholars say the movement was non-voluntary and induced, largely comprised of poor tribesmen migrating to raise the required head tax imposed by colonial administration to create labour for the emerging colonial economy (see for example Anich (2014) and Mavhunga (2008). Other scholars have argued that Africans migrated in response to the attractive opportunities of the new cities and the possibility of liberty from traditional control, (Brycesson 2001). It is more likely that migration arose from a combination of these two processes but the debate illustrates questions of agency in migration decision making.

The 1960s and 1970s saw two distinct patterns which illustrate the factors at play in migration decisions. During the 1960s Africans shifted their migration to South Africa, the main destination being the gold fields. In many ways this migration can be considered involuntary, given the very low standard of living of most of the population, although some young African males would undertake such migration to indicate their manhood and readiness to assume marriage. As with the migration of the early 1900s, this regional migration was circular, migrants oscillating between home and destination (Muzvidziwa, 2001).

A further development in this old migration arose in the late 1970s. The long war for independence caused massive internal and external migration in search of secure zones. Towns tended to be relatively safer than rural villages, explaining why Salisbury and Bulawayo were attractive destinations (Anich et al 2014). Such rural to urban migration was characterised by a return to the home as soon as the war pressure eased. This is the old migration, largely personal, circular and political.

The "new" migration starts after independence in the 1980s and continues to the present. This migration is produced by economic reforms and can be described as having two waves. The first wave of this migration peaks in the late 1990s in response to structural adjustment 
with the second wave peaking in the 2000s following a populist land reform that saw in 2008 the virtual collapse of the economy with GDP contracting by $50 \%$, inflation peaking at $231,000,000 \%$ in July and capacity utilisation in industry falling below $10 \%$ (Zimbabwe Country Analysis Report 2014). Unemployment rose to over 70\%, resulting in scores of people migrating from the country in search of better opportunities. ${ }^{1}$ This then is the new migration, a movement of people that is largely driven by economic circumstances.

The degree to which this delineation of migration is applicable may be contested but it is beyond doubt that migration in Zimbabwe has a long history. It starts in colonial times and continues in the post-independence state in response to economic pressure. In the section below we look at the patterns of current migration.

\section{Patterns of the New Migration in Zimbabwe}

The exact number of people who have emigrated is not known. It is estimated that 2 to 3 million Zimbabweans are working and living in the Diaspora. ${ }^{2}$ Of this total, 1 to 1.5 million Zimbabweans are conservatively estimated to be living in South Africa alone, with at least 20\% estimated to be "irregular", (Crush and Tevera 2010, Alich et al 2014). In Zimbabwe's high migrant sending areas (including Chiredzi, Chipinge, Gwanda, Bulilima and Plumtree), more than $80 \%$ of households have at least one family member who is an irregular migrant, (United Nations Zimbabwe Country Analysis Report 2014, Raftopolous 2011, Bracking and Sachikonye 2006).

Regarding the nature of migrants leaving Zimbabwe during this time, it is possible to identify two groups. The first, and largest, group consists of unskilled workers. These migrants choose nearby destinations such as South Africa. They tend to work for relatively short periods and in menial jobs, for example as farm labourers, domestic works and casual workers. Crush, Chikanda and Tawodzera (2012), and others, describe some of this group as survival

\footnotetext{
1 See Landau (2008), Dzingirai, Mutopo and Landau (2014) and Mugabe et al 2012) for a more detailed discussion.

${ }^{2}$ According to the latest Census, Zimbabwe has a population of around 13 million (Zimbabwe National Statistics Agency, 2012)
} 
migrants, ${ }^{3}$ fleeing persecution and extensive livelihood breakdown in Zimbabwe but that more broadly the profile of migrants from Zimbabwe to South Africa is mixed, consisting of both refugees seeking long term refugee, and those seeking temporary economic opportunities, with a range of motivations and intentions concerning duration.

One feature of the mixed nature of migration from Zimbabwe is that it also includes professionals. Regarding the exodus of skilled professionals, 20,000 health care professionals are believed to have left the country since the turn of the new millennium. These professionals are working in the United Kingdom, New Zealand, Australia and Namibia. The Middle East and Asia are not professionals' preferred destination, except for some very specific sectors of engineering, aviation and insurance. Zanamwe and Devillard (2009), Crush, Chikanda and Tawodzera (2012) and Anich et al (2014) provide excellent discussions of brain drain in the context of migration from Zimbabwe.

\section{Linkages between Poverty and Migration}

The causes or triggers of migration in Zimbabwe appear to be associated strongly with poverty (Dzingirai et al, 2014). The literature suggests that migrants tend to be those who are no longer employed as a result of closure of industries (Raftopolous, 2011) and are people living on less than a dollar a day, (Bracking and Sachikonye 2006, Raftoplous 2011). Furthermore migrants are drawn from households whose consumption expenditure per capita is below the food poverty line. Poverty is indeed severe in Zimbabwe: the United Nations Country Office report (UN, 2014) suggests that almost $80 \%$ of the rural population is poor, compared to just under $40 \%$ in urban areas.

But if poverty gives rise to migration, it appears to be eased by it. A recent study suggests that households with migrants are better off than those who do not have migrants (Crush, Chikanda and Tawodzera 2012; Anich et al 2014). One important channel for this is remittances. While some of migrant income is remitted formally, through for example

\footnotetext{
${ }^{3}$ Crush, Chikanda and Tawodzera (2012) provide a detailed profile of Zimbabwean migrants living in South Africa using data on a sample of 500 migrants living in Cape Town and Johannesburg in 2010.
} 
transfer agencies and, more recently, mobile banking, much of it is through informal networks based on trust (Bracking and Sachikonye 2006). The use of 'omalaitshas', personal couriers, relatives and spouses and other religious networks are noteworthy forms of remitting income and goods. Because they are based on trust, these forms have their own risks. However, they remain attractive to the poor migrants who often cannot afford formal channels of remitting income or goods (Dzingirai et al, 2014).

Regarding its use, remitted income is often used to ensure food security among sending households (Crush and Tevera 2010,). While it is true that a large part of remitted income is invested in non-productive areas such as funerals, marriage, and ceremonies, and of course food, (Dzingirai, Mutopo and Landau, 2014), it appears that some is directed towards economic production, including purchasing of livestock, land and small business (Bracking and Sachikonye, 2006; Zanamwe and Devillard, 2009).

Clearly there is indication that migration can help alleviate or reduce poverty. To be sure, there are serious questions about the circumstances under which migration can be expected to reduce poverty and about the developments and reforms of the financial sector that might be required to facilitate easy repatriation of remittances. But that migration seems to constitute a step away from poverty if not out of it, is not a tenuous hypothesis. The challenges however in demonstrating empirically such as link cannot be overstated. Empirically there are challenges in establishing causality with available data and moreover understanding whether migration leads to lower poverty levels depends qualitatively on how one defines the inverse relationship between poverty reduction and migration strategies, (Dzingirai, Mutopo and Landau, Crush, Chikanda and Tawodzera 2012).

\section{Survey Methodology}

The Zimbabwe household survey follows protocols used in other countries that form part of the MOOP consortium, namely a core household questionnaire and a sampling strategy that ensures reasonably large sub-samples of households with and without migrants. Our approach differs from that of Crush, Chikanda and Tawodzera 2012, and others, in that we 
capture data on the original household of the migrants, as opposed to interviewing migrants themselves, and we also have a group of households without any currents migrants which may be considered as a control group for our research. We define a migrant as a former member of the household who within the last 10 years has moved away from the village for at least three months for either work or study reasons and is currently away. ${ }^{4}$ We distinguish between internal migration and regional and international migration by capturing destination.

This study was undertaken in three districts in Zimbabwe, namely Chivi in Masvingo province in the south-east of the country, Gwanda in Matelebleland province in the south-west and Hurungwe in Mashonaland West province, in the north, areas where the CASS team in collaboration with WITS had already conducted qualitative research and had established relationships with district officials and village elders.

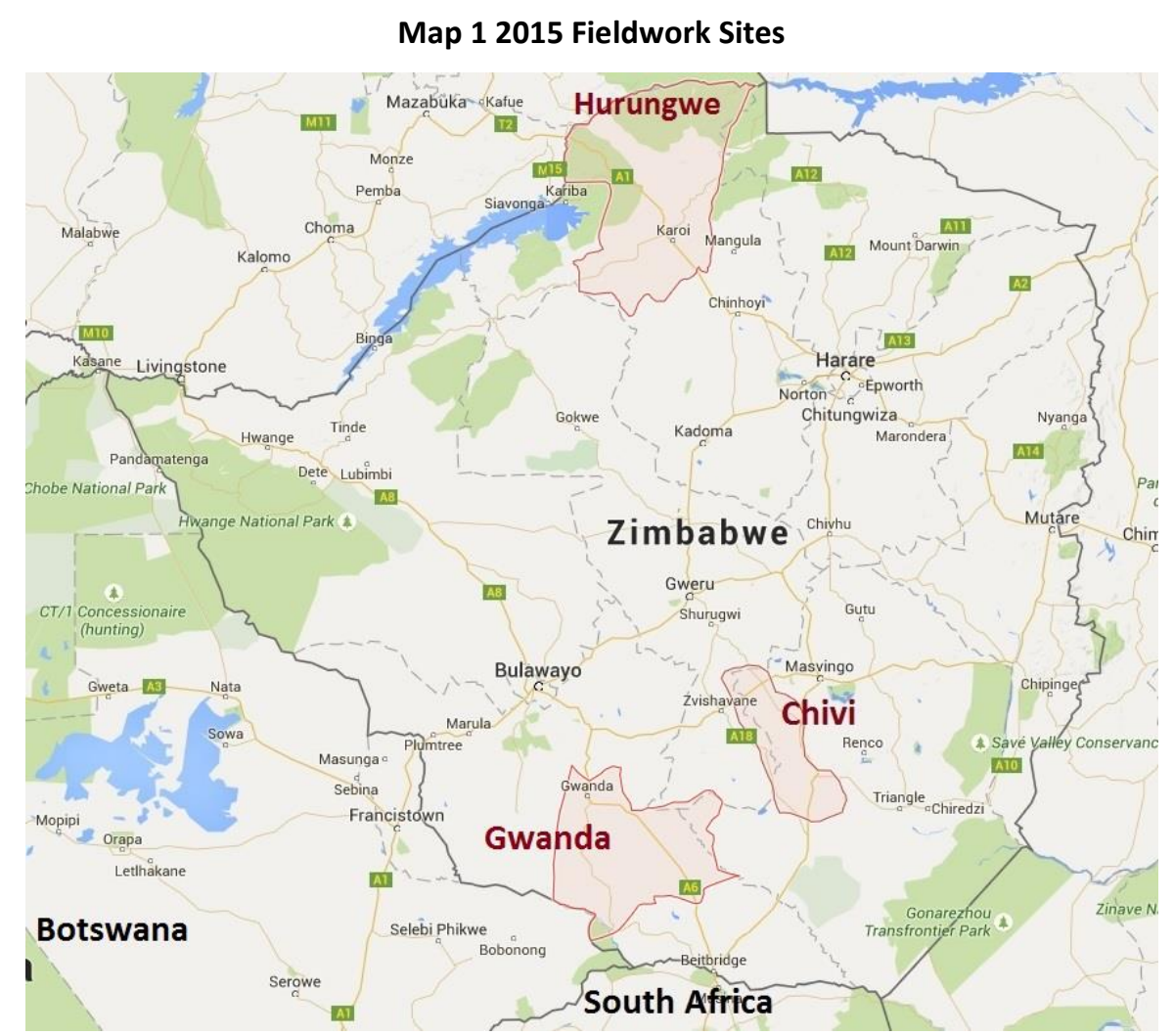

In each district, two wards were selected, one close to the district's main town and the other some distance away, in order to facilitate eventually analysis of the role of proximity in

\footnotetext{
${ }^{4}$ We have collected some data on return migrants but will not explore that data here.
} 
migration decisions. From each of the selected wards, two villages (in practice VIDCOs, Village Development Committee,) were randomly selected. In each of the selected villages, listing of households was obtained from the village development chairperson. Using a number of key informants in each village, each household was categorised in terms of whether it had migrants or not. For the purpose of this household listing, migrants were defined as any member who was currently living outside the VIDCO for a continuous period of 3 months or more, irrespective of when the household member migrated as we did not expect key informants to have precise information on date of migration. One hundred households were then selected randomly from these lists in a ratio of 3:1, that is, 75 households with migrants and 25 households without migrants, giving a total intended sample size of 1200 households.

In practice, sampling based on information provided by key informants was more accurate in some areas that others. While an attempt was made to replace households wrongly sampled, distances between households made this difficult in some areas. The resultant sample is slightly more heavily weighted towards households without migrants in Gwanda but otherwise broadly as planned in Chivi and Hurungwe. The relatively low proportion of households with migrants in Gwanda (65\% of the sample rather than the intended $75 \%$ ) reflects concern by households with migrants in the area to volunteer information that could be used against their migrants in South Africa in the context of xenophobia. Table 1 below shows the sample broken down by district and migrant characteristics of the household.

While we used purposive sampling to select households with and without migrants, the breakdown between internal and international migrants within the group of households with migrants was not specified. Our sample reveals an interesting difference between the three districts. In Hurungwe, we observe that a far greater proportion of households with migrants have internal migrants (migrants still living within Zimbabwe), with relatively few households in Hurungwe having migrants living outside of the country. Chivi or Gwanda, both located close to the southern border with South Africa, have a much higher proportion of households with migrants located outside of the country: in Chivi, almost $72 \%$ of households have one or more migrants living abroad.

Table 1: Household sample by region and migrant status 


\begin{tabular}{|c|c|c|c|c|c|c|c|c|c|c|}
\hline \multirow[b]{2}{*}{ District } & \multicolumn{2}{|c|}{$\begin{array}{l}\text { Households } \\
\text { with Internal } \\
\text { migrants }\end{array}$} & \multicolumn{2}{|c|}{$\begin{array}{l}\text { Households } \\
\text { with } \\
\text { International } \\
\text { migrants }\end{array}$} & \multicolumn{2}{|c|}{$\begin{array}{l}\text { Households } \\
\text { with both } \\
\text { Internal and } \\
\text { International } \\
\text { migrants }\end{array}$} & \multicolumn{2}{|c|}{$\begin{array}{l}\text { Households } \\
\text { with no } \\
\text { migrants }\end{array}$} & \multicolumn{2}{|c|}{ Total } \\
\hline & $N$ & Col \% & $N$ & Col \% & $N$ & Col \% & $N$ & Col \% & $N$ & Col \% \\
\hline Chivi & 85 & 25.1 & 190 & 45.8 & 27 & 26 & 98 & 29.3 & 400 & 33.5 \\
\hline Hurungwe & 202 & 59.6 & 74 & 17.8 & 24 & 23.1 & 99 & 29.6 & 399 & 33.4 \\
\hline Gwanda & 52 & 15.3 & 151 & 36.4 & 53 & 51 & 138 & 41.2 & 394 & 33 \\
\hline Total & 339 & 28.4 & 415 & 34.8 & 104 & 8.7 & 335 & 28.1 & 1,193 & 100 \\
\hline
\end{tabular}

Our household survey questionnaire is similar in design to those developed by the consortium for other countries. It consists of several modules, including a household roster and a roster of migrant members, with details of gender, age, education, marital status and employment. Note that information on current migrants is provided by the household and thus there is inevitably some reporting error. ${ }^{5}$ Households are asked to report further on the migration history of each member: when they last migrated, and why, where they are currently living and what their activities are, and also to report on remittances in cash and in goods received from each migrant. One innovative feature of our questionnaire is that we have a strong focus on decision making, with questions relating to the decision to migrate, decision making over use of remittances, and on migrant networks. A consumption module captures data on main items of food and non-food consumption, using a module similar in design but narrower in focus to the Living Standards Measurement Surveys consumption modules ${ }^{6}$ and will eventually enable us to analyse the effect of remittances on expenditure shares. We also capture objective indicators of living standards (land and housing characteristics) and subjective perceptions of welfare and of the household's migration experience.

\section{Profile of Migrants and their Households}

We begin by describing some basic characteristics of households with and without migrants, as shown in Table 2. We observe very small differences in the size of households and little

\footnotetext{
${ }^{5}$ It is not obvious how we might establish the extent of reporting errors without tracking migrants at their current location.

${ }^{6}$ Based on our recent survey in Ethiopia, we estimate we capture around $80 \%$ of household food expenditure.
} 
difference in the number of migrants each type of household sends. We can say that households with migrants tend to be older, in that the mean age of the head of the household is higher for households with migrants, suggesting there are life-cycle processes involved in migration decisions, although not so much higher to suggest there are significant differences in demographic structure between households with and households without migrants. Households with migrants tend to be slightly more likely to have a female head than those without, which perhaps suggests a longer term pattern of male migration and male absence form households. The meaning of the term household head also needs to be understood from a local Shona perspective. Household heads in Zimbabwe are referred to as samusha, a mature male who has independent status from his parents. This male individual would normally have with his own village plot, fields, a wife and children. This particular person should be able to fend for the whole clan and not rely on his immediate family members for survival (Mutopo 2014). It is not clear how this might change in the face of long term male migration.

There are some small differences in the educational attainment of household heads but generally migrants are drawn from households with heads who have either primary or middle school education. 


\begin{tabular}{|c|c|c|c|c|c|c|c|c|c|c|}
\hline & \multicolumn{2}{|c|}{ All } & \multicolumn{2}{|c|}{$\begin{array}{l}\text { Households } \\
\text { with } \\
\text { Internal } \\
\text { migrants }\end{array}$} & \multicolumn{2}{|c|}{$\begin{array}{l}\text { Households } \\
\text { with } \\
\text { International } \\
\text { migrants }\end{array}$} & \multicolumn{2}{|c|}{$\begin{array}{l}\text { Households } \\
\text { with both } \\
\text { Internal and } \\
\text { International } \\
\text { migrants }\end{array}$} & \multicolumn{2}{|c|}{$\begin{array}{c}\text { Households } \\
\text { with no } \\
\text { migrants }\end{array}$} \\
\hline & $N$ & Mean & $N$ & Mean & $N$ & Mean & $N$ & Mean & $N$ & Mean \\
\hline Household size & 1193 & 5.05 & 339 & 4.74 & 415 & 5.31 & 104 & 4.92 & 335 & 5.10 \\
\hline Number of migrants & 1193 & 1.28 & 339 & 1.46 & 415 & 1.69 & 104 & 3.18 & 0 & 0.00 \\
\hline \multicolumn{11}{|l|}{ Household head: } \\
\hline Age & 1144 & 54.99 & 321 & 54.17 & 390 & 57.08 & 104 & 61.26 & 329 & 51.34 \\
\hline Female & 424 & 0.37 & 117 & 0.36 & 155 & 0.40 & 40 & 0.38 & 112 & 0.34 \\
\hline \multicolumn{11}{|l|}{ Education: } \\
\hline None & 122 & 0.11 & 34 & 0.11 & 51 & 0.13 & 7 & 0.07 & 30 & 0.09 \\
\hline Primary & 519 & 0.46 & 127 & 0.40 & 180 & 0.47 & 68 & 0.65 & 144 & 0.45 \\
\hline Middle & 409 & 0.36 & 136 & 0.43 & 123 & 0.32 & 23 & 0.22 & 127 & 0.39 \\
\hline High & 39 & 0.03 & 6 & 0.02 & 17 & 0.04 & 0 & 0.00 & 16 & 0.05 \\
\hline Other & 39 & 0.03 & 13 & 0.04 & 14 & 0.04 & 6 & 0.06 & 6 & 0.02 \\
\hline
\end{tabular}

Turning to the migrants themselves, we show basic characteristics by gender of the migrant, in Table 3. The first striking observation is that the majority, $72 \%$, of migrants identified in our sample are male. We also observe that female migrants on average have been away for a period of 31 months, compared to 41 months for male migrants. This suggests that women are less disposed to migrate than men but perhaps too that female migration is a more recent phenomenon than among men. ${ }^{7}$ Certainly there is evidence from other studies that female migration has been increasing in recent years (see Criuh and Tavera, 2010). Migrants also tend to be quite old: around 32 years old, older than the stereotypical youth, and older than the (adult) non-migrants in our sample (see Appendix Table A1 for non-migrant characteristics). The majority of migrants are sons or daughters of the household head.

In terms of education, there is little difference between men and women migrants, with most having either primary or middle school education. However they seem slightly better educated than non-migrants: Table A1 suggest that around $13 \%$ of non-migrants have no education, compared to just $1 \%$ of our migrants.

\footnotetext{
${ }^{7}$ Note that we are not recording completed periods of migration here: instead our data shows how long current migrants have been away.
} 
In terms of destination, surprisingly few differences exist between men and women migrants. Just over $40 \%$ of each remain within Zimbabwe, with well over $50 \%$ migrating to other countries within Africa, including South Africa and other southern African countries. Few go as far afield as the UK, USA or Canada or to other international destinations such as the Middle East. On average, around half of the migrants in our sample send money ${ }^{8}$ back home to their families, with men being slightly more likely to remit than women. Of those migrants who remit, they remit approximately US\$350 per year, and this differs substantially by gender. Male migrants send around $50 \%$ more than female migrants, which given they are approximately the same age, and approximately the same education and in the same destinations as women migrants, is surprising. ${ }^{9}$

\footnotetext{
${ }^{8}$ We report here only on cash remittances, not the value of goods sent home.

${ }^{9}$ It is possible that the difference in cash remittances is made up with goods taken or sent home, yet to be explored.
} 


\begin{tabular}{|c|c|c|c|c|c|c|}
\hline & \multicolumn{2}{|c|}{ All migrants } & \multicolumn{2}{|c|}{ Male } & \multicolumn{2}{|c|}{ Female } \\
\hline & Mean & $N$ & Mean & $N$ & Mean & $N$ \\
\hline Age & 31.7 & 1393 & 32.5 & 1002 & 29.8 & 391 \\
\hline \multicolumn{7}{|l|}{ Education } \\
\hline None & 0.01 & 10 & 0.01 & 8 & 0.00 & 2 \\
\hline Primary & 0.24 & 359 & 0.24 & 256 & 0.25 & 103 \\
\hline Middle & 0.64 & 953 & 0.63 & 680 & 0.66 & 273 \\
\hline High & 0.09 & 139 & 0.10 & 112 & 0.07 & 27 \\
\hline Other & 0.02 & 33 & 0.02 & 23 & 0.02 & 10 \\
\hline \multicolumn{7}{|l|}{ Destinations } \\
\hline Internal: Within same province in Zimbabwe & 0.18 & 267 & 0.17 & 188 & 0.19 & 79 \\
\hline Internal: Other province in Zimbabwe & 0.26 & 391 & 0.27 & 296 & 0.23 & 95 \\
\hline International: Other African country & 0.54 & 822 & 0.53 & 581 & 0.57 & 241 \\
\hline $\begin{array}{r}\text { International: English speaking outside } \\
\text { Africa (eg UK, USA) }\end{array}$ & 0.03 & 43 & 0.03 & 36 & 0.02 & 7 \\
\hline $\begin{array}{r}\text { International: Other international } \\
\text { destination }\end{array}$ & 0.00 & 1 & 0.00 & 1 & 0 & 0 \\
\hline $\begin{array}{l}\text { Average annual remittances sent by migrant } \\
\text { in USD }\end{array}$ & 348.15 & 795 & 381.43 & 592 & 251.10 & 203 \\
\hline Time of migration in months & 38.78 & 1488 & 41.64 & 1074 & 31.34 & 414 \\
\hline Household size & 5.15 & 1530 & 5.05 & 1104 & 5.40 & 426 \\
\hline Age of household head & 58.10 & 1477 & 57.69 & 1059 & 59.14 & 418 \\
\hline Female household head & 0.39 & 573 & 0.39 & 415 & 0.38 & 158 \\
\hline \multicolumn{7}{|l|}{ Education of household head } \\
\hline None & 0.11 & 158 & 0.12 & 123 & 0.08 & 35 \\
\hline Primary & 0.52 & 758 & 0.49 & 509 & 0.60 & 249 \\
\hline Middle & 0.31 & 451 & 0.33 & 341 & 0.27 & 110 \\
\hline High & 0.02 & 31 & 0.02 & 22 & 0.02 & 9 \\
\hline Other & 0.04 & 60 & 0.05 & 48 & 0.03 & 12 \\
\hline \multicolumn{7}{|l|}{ Relationship to household head } \\
\hline Head & 0.08 & 119 & 0.10 & 115 & 0.01 & 4 \\
\hline Spouse/Partner & 0.05 & 71 & 0.05 & 60 & 0.03 & 11 \\
\hline Son/daughter & 0.66 & 1005 & 0.64 & 701 & 0.71 & 304 \\
\hline
\end{tabular}

However, when we break down remittances further, as shown in Table 4, we see that while, irrespective of destination, migrant women are less likely to remit than men, it cannot be concluded that they always remit less. We also observe that for male migrants, remittances are on average higher when sent from international destinations than from internal destinations; the converse is true for women. 


\begin{tabular}{|l|c|c|c|c|}
\hline $\begin{array}{l}\text { Table 4: Annual remittances in USD sent by migrants from different destinations by sex of } \\
\text { migrant }\end{array}$ & \multicolumn{2}{|c|}{ Male } & \multicolumn{2}{c|}{ Female } \\
\cline { 2 - 5 } & Mean & $N$ & Mean & $N$ \\
\hline Internal: Within same province in Zimbabwe & 425.56 & 101 & 156.89 & 28 \\
\hline Internal: Other province in Zimbabwe & 331.22 & 183 & 401.35 & 51 \\
\hline International: Other African country & 387.44 & 290 & 202.67 & 117 \\
\hline International: English speaking (eg UK, USA) & 578.31 & 16 & 666.67 & 3 \\
\hline International: Other international destination & 0.0 & 0 & 0.0 & 0 \\
\hline All & 381.43 & 592 & 251.10 & 203 \\
\hline
\end{tabular}

The difference in remittance amounts by gender is perhaps best explained by considering the occupational differences at destination. Table A2 shows a detailed breakdown of remittances by occupation and gender. The single most frequent occupations for men is in skilled construction work whereas for women, domestic service is the most frequent occupation: our data shows that men working in construction send almost US\$500 a year compared to around US\$250 for female domestic workers. Male migrants are also more likely to be in higher paid technical/professional occupations than female migrants, although for this group, our data shows that women remit more than men. It is possible that there are differences in wage levels, or differences in employment conditions, which lead to different remittance behaviour.

\section{Migration and poverty}

We adopt two approaches to explore the relationship between migration and poverty. First we examine our survey data on consumption to see if there is any association between consumption levels and migrant status of households. Figure 1 shows the distribution of annualised total household per capita consumption for each group of households; means and standard deviations for total household per capita consumption as well as on key expenditure groups (food, education health etc) are shown in Table 5; and Table 6 shows expenditure shares. 
We see that households without migrants are on average slightly worse off than households with migrants. Households with both internal and international migrants appear to the better off, although there is little difference between households with only internal migrants and households with only international migrants. Expenditure shares, including the food budget share, are very similar across groups, surprisingly even when comparing the better off households with both types of migrants with the rest of the sample. Here we confront a significant difficulty in reaching firmer conclusions as we do not observe consumption levels prior to the migration decision: we cannot be sure that any differences are due to migration, or if those differences provoked or hindered the migration decision. We intend to explore this in future work.

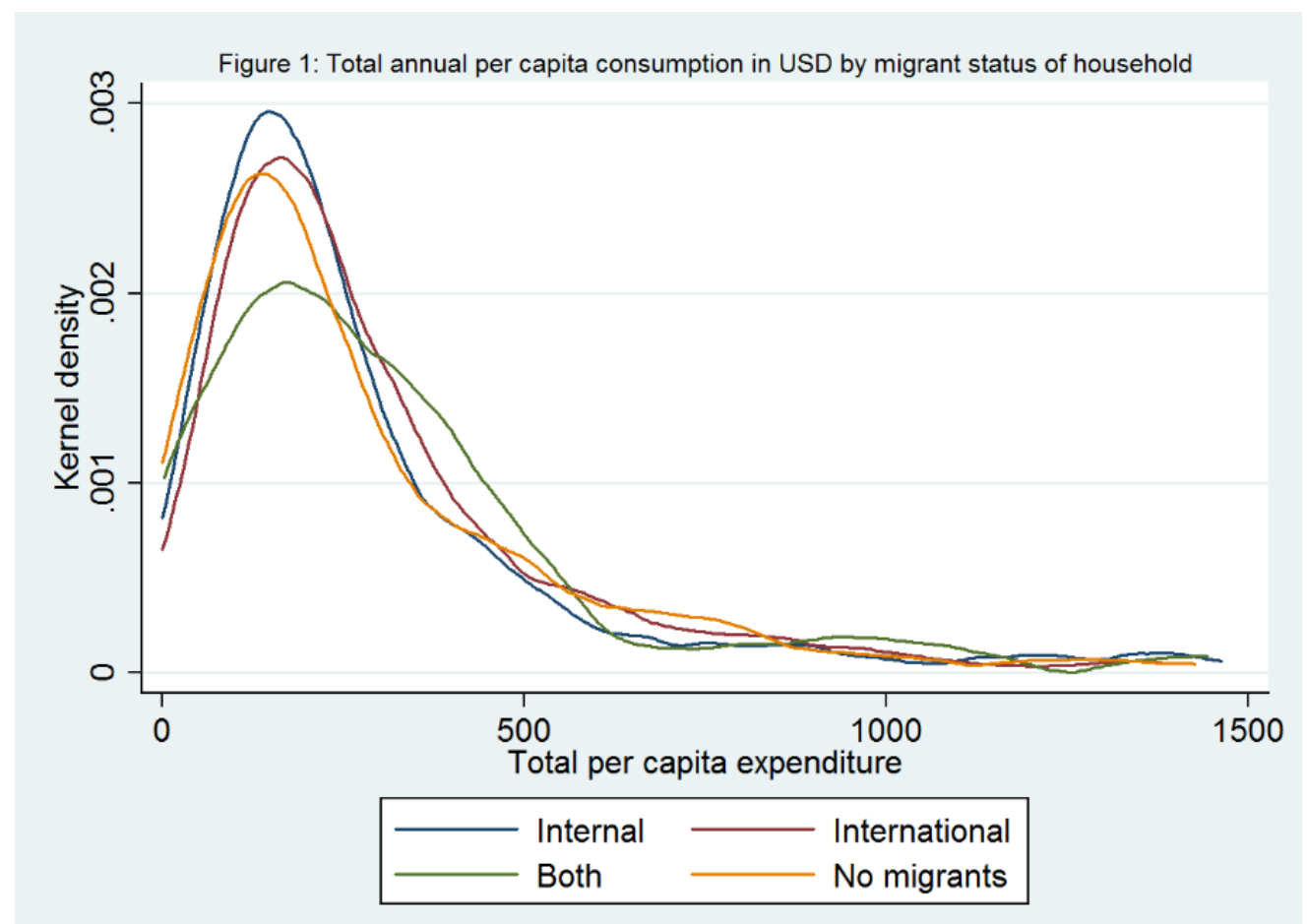




\begin{tabular}{|c|c|c|c|c|c|c|c|c|}
\hline & & Total & Food & $\begin{array}{l}\text { Household } \\
\text { items }\end{array}$ & Education & Health & Alcohol & Transport \\
\hline \multirow{2}{*}{ All $(N=1,192)$} & Mean & 353.8 & 207.0 & 77.1 & 30.4 & 7.8 & 10.5 & 27.6 \\
\hline & SD & 640.7 & 566.8 & 168.3 & 65.6 & 21.9 & 37.4 & 50.2 \\
\hline $\begin{array}{l}\text { Households } \\
\text { with Internal }\end{array}$ & Mean & 359.4 & 208.4 & 77.5 & 30.9 & 8.4 & 9.9 & 24.8 \\
\hline $\begin{array}{l}\text { migrants } \\
(N=339)\end{array}$ & SD & 575.3 & 456.9 & 160.5 & 71.5 & 23.7 & 46.7 & 54.9 \\
\hline $\begin{array}{l}\text { Households } \\
\text { with }\end{array}$ & Mean & 346.5 & 216.2 & 69.0 & 30.3 & 8.2 & 9.4 & 30.5 \\
\hline $\begin{array}{l}\text { International } \\
\text { migrants } \\
(N=415)\end{array}$ & SD & 826.7 & 799.1 & 135.9 & 54.2 & 22.1 & 24.8 & 54.0 \\
\hline $\begin{array}{l}\text { Households } \\
\text { with Both }\end{array}$ & Mean & 448.0 & 279.8 & 91.5 & 26.5 & 5.4 & 6.2 & 21.1 \\
\hline $\begin{array}{l}\text { International } \\
\text { and Internal } \\
\text { migrants } \\
(N=103)\end{array}$ & SD & 643.3 & 525.4 & 275.3 & 43.5 & 18.3 & 21.1 & 44.1 \\
\hline None & Mean & 328.2 & 171.9 & 82.2 & 31.2 & 7.6 & 13.4 & 29.4 \\
\hline$(N=335)$ & SD & 389.5 & 235.8 & 169.5 & 77.1 & 20.9 & 40.2 & 40.9 \\
\hline
\end{tabular}

\begin{tabular}{|c|c|c|c|c|c|}
\hline & All & $\begin{array}{l}\text { Households } \\
\text { with } \\
\text { Internal } \\
\text { Migrants }\end{array}$ & $\begin{array}{l}\text { Households } \\
\text { with } \\
\text { International } \\
\text { Migrants }\end{array}$ & $\begin{array}{l}\text { Households } \\
\text { with Both } \\
\text { internal and } \\
\text { International } \\
\text { Migrants }\end{array}$ & $\begin{array}{c}\text { Households } \\
\text { with no } \\
\text { Migrants }\end{array}$ \\
\hline Food & 0.56 & 0.55 & 0.58 & 0.56 & 0.55 \\
\hline Household items & 0.22 & 0.22 & 0.21 & 0.21 & 0.23 \\
\hline Education & 0.11 & 0.11 & 0.12 & 0.09 & 0.10 \\
\hline Health & 0.03 & 0.03 & 0.03 & 0.02 & 0.03 \\
\hline Other & 0.08 & 0.09 & 0.06 & 0.12 & 0.19 \\
\hline
\end{tabular}

Given the difficulties of drawing strong inferences from the consumption data, our second approach to exploring whether migration enables households to escape poverty, is simply to ask them. First we asked households if generally they felt households with migrants were better off. Table 7 shows that a majority of households responded that they did think that households were better off if they had migrants, although a sizeable $44 \%$ believe the opposite. Interestingly among households with migrants, those with family members abroad 
(primarily in South Africa and southern Africa) were very negative on the impacts of migration: $52 \%$ felt that migration was beneficial. This may reflect concerns for safety of migrants in South Africa: our fieldwork coincided with the recent escalation in xenophobic violence. Thus while we may conclude that there is a widespread belief among our sample that migration is generically beneficial, much may depend on the destination of the migrant, a nuance we will explore in further work.

\begin{tabular}{|c|c|c|c|c|c|c|c|c|c|c|}
\hline \multirow{2}{*}{$\begin{array}{l}\text { Table 7: Res } \\
\text { community } \\
\text { migrants?" }\end{array}$} & \multicolumn{2}{|c|}{$\begin{array}{l}\text { Households } \\
\text { with } \\
\text { Internal } \\
\text { Migrants }\end{array}$} & \multicolumn{2}{|c|}{$\begin{array}{l}\text { Households } \\
\text { with } \\
\text { International } \\
\text { Migrants }\end{array}$} & \multicolumn{2}{|c|}{$\begin{array}{l}\text { Households } \\
\text { with both } \\
\text { Internal and } \\
\text { International } \\
\text { Migrants }\end{array}$} & \multicolumn{2}{|c|}{$\begin{array}{l}\text { Households } \\
\text { with no } \\
\text { Migrants }\end{array}$} & \multicolumn{2}{|c|}{ Total } \\
\hline & $N$ & $\%$ & $N$ & $\%$ & $N$ & $\%$ & $N$ & $\%$ & $N$ & $\%$ \\
\hline No & 120 & 36.5 & 210 & 52.2 & 37 & 38.9 & 129 & 40.1 & 496 & 43.2 \\
\hline Yes & 207 & 62.9 & 189 & 47 & 58 & 61.1 & 184 & 57.1 & 638 & 55.6 \\
\hline Don't know / Refusal & 2 & 0.6 & 3 & 0.6 & 0 & 0 & 9 & 2.7 & 14 & 1.1 \\
\hline Total & 329 & 100 & 402 & 100 & 95 & 100 & 322 & 100 & 1,148 & 100 \\
\hline
\end{tabular}

When we asked households with migrants to reflect on their own situation, and consider if their household was better or worse off since their member had migrated, we see that around $40 \%$ of households report that they their own situation has improved and only around $22 \%$ report that it has declined. Again we see, in Table 8, that those with international migrants have a less positive view of the impact of migration on their households, in contrast to those with only internal migrants or both internal and international migrants. 


\begin{tabular}{|c|c|c|c|c|c|c|c|c|}
\hline & \multicolumn{2}{|c|}{$\begin{array}{c}\text { Households } \\
\text { with Internal } \\
\text { Migrants }\end{array}$} & \multicolumn{2}{|c|}{$\begin{array}{l}\text { Households } \\
\text { with } \\
\text { International } \\
\text { Migrants }\end{array}$} & \multicolumn{2}{|c|}{$\begin{array}{l}\text { Households } \\
\text { with Both } \\
\text { Internal and } \\
\text { International } \\
\text { Migrants }\end{array}$} & \multicolumn{2}{|c|}{ Total } \\
\hline & $N$ & $\%$ & $N$ & $\%$ & $N$ & $\%$ & $N$ & $\%$ \\
\hline Much improved & 14 & 4.1 & 10 & 2.4 & 4 & 3.8 & 28 & 3.2 \\
\hline Improved & 132 & 39.1 & 141 & 34.1 & 45 & 43.3 & 318 & 36.9 \\
\hline Neither improved nor getting worse & 128 & 37.9 & 149 & 36 & 33 & 31.7 & 310 & 36.6 \\
\hline Worse & 56 & 16.6 & 93 & 22.5 & 17 & 16.3 & 166 & 19.3 \\
\hline Much worse & 8 & 2.4 & 20 & 4.8 & 5 & 4.8 & 33 & 3.8 \\
\hline Don't know / Refusal & 0 & 0 & 1 & 0.2 & 0 & 0 & 1 & 0.1 \\
\hline Total & 338 & 100 & 414 & 100 & 104 & 100 & 856 & 100 \\
\hline
\end{tabular}

\section{Conclusions}

This working paper reports preliminary findings from a survey conducted in April and May 2015 on a sample of households in Zimbabwe comprising of both households with current migrants and households without migrants. Our sample of almost 1200 households is relatively large compared to other surveys exploring Zimbabwean migration and moreover covers migration both with the country and to international destinations, not just South Africa.

The literature suggests that migrants tend to be poor and often driven by unemployment, vulnerable livelihoods and insecurity. Our findings do not dispute that. What is not clear from the existing evidence is whether migrants are disproportionately drawn from the poor or whether there is a group of households or individuals in Zimbabwe too poor to migrate. Our preliminary results suggest that there are few differences between migrants and nonmigrants, except that the former tend to be slightly better educated, and that generally households with migrants are not better off than those without. We observe little difference in household consumption expenditure levels between households of different migration statuses. While acknowledging difficulties in drawing conclusions about welfare from the 
simple descriptives of our expenditure data presented here, there does appear to be a negative perception of the benefits of migration among those households who have migrants abroad, in contrast to those whose migrant members remain within the country. As our sample of international migrants are predominantly based in South Africa, we infer this to be related to recent xenophobic attacks. In a related qualitative study in the same regions, a similar observation was made, but this negative perception was more likely to be held by households with long-term migrants abroad (Dzingirai et al 2014). It appeared that the longer the migrant stayed abroad, the more disappointing their contribution became. This suggests that perceptions, if not objective indicators of poverty, may be influenced by the destination of the migrant but also by the duration of the migration episode, a theme we will return to in future work.

Further work will aim to explore the role of destination and duration of migration on poverty, and in particular the role of remittances in household economies. We will explore further the different factors associated with migration, such as low income, poor asset endowment, unemployment or livelihood insecurity, and how different individuals and their families respond to these different factors. 


\section{References}

Anich, R, Crush, J, Melde, S and Ouchu, D 2014. A New Perspective on Human Mobility in the South, Springer, London

Bracking, S and Sachikonye, L. 2006. Remittances, Poverty Reduction and the Informalisation of the Household Well-being in Zimbabwe, Working Paper, No 45, Global Poverty Research Group, Oxford.

Brycesson, D. F. 2001. De-agrarianisation and Rural Employment in Southern Africa, African Studies Centre and Brill Publishers, Leiden.

Crush, J and Tevera, D. 2010. Exiting Zimbabwe in J Crush and D. Tevera, (Eds), Zimbabwe`s Exodus, Crisis, Migration and Survival, Southern African Migration Programme, Cape Town.

Crush, J, Chikanda, A and Tawodzera, G. 2012. The Third Wave: Mixed Migration from Zimbabwe to South Africa, Southern African Migration Programme, Cape Town.

Dzingirai, V, Mutopo, P and Landau, L. 2014. Confirmations, Coffins and Corn: Kinship, Social Networks and Remittances from South Africa to Zimbabwe, Migrating out of Poverty Research Programme, University of Sussex, Sussex.

Landau, L. 2008. Migration in the Southern African Development Community: Zimbabwean Migrants in South Africa. Centre for Migration Studies, University of Witwatersrand, Johannesburg.

Mavhunga, C. 2008. The Mobile Workshop: Mobility, Technology, in Zimbabwe, ProQuest Publishers, Parkway.

Mugabe, P.H. 2012. Land Reform Migrations and Forest Resources Management in Chimanimani District, Zimbabwe, in (eds) S. Hecht, S. Kandel and A. Morales Migrations, rural Livelihoods and Natural Resources Management. IDRC, Prisma pp 5577

Mutopo, P. 2014. Women, Land and Mobility in Zimbabwe: Experiences of Fast Track Land Reform, Brill Publishers, Leiden.

Muzvidziwa, 2001, Zimbabwe's Cross-Border Women Traders: Multiple Identities and Responses to New Challenges, Journal of Contemporary African Studies, No 19.

Raftopolous, B. 2011. A Study on Migration and Remittances in Matebeleland, Zimbabwe, Solidarity Peace Trust, Cape Town.

United Nations, Zimbabwe Country Office Working Report 2014, on Country Situational Analysis, Harare. 
United Nations, Zimbabwe Country Office Report, 2015 accessed on, 8 August 2015, http//www.unzimoffice.org.

World Bank Poverty Data files 2015, accessed on 8 August 2015, http/www.worldbank.povertyfiles.org

Zanamwe, L and Devillard, A. 2009. Migration in Zimbabwe: A Country Profile, Study Commissioned by the Zimbabwe National Statistical Agency (ZIMSTATS) and the International Organisation for Migration, Harare.

Zimbabwe Central Statistical Office Report on Poverty 2012, accessed on 8 August 2015, http/ www.zimsstatsoffice.co.zw

Zimbabwe National Statistics Agency 2013, Census 2012: National Report; accessed on 10 September 2015 http://www.zimstat.co.zw/dmdocuments/Census/CensusResults2012/National Rep ort.pdf 


\section{Appendix}

\begin{tabular}{|c|c|c|c|c|c|c|}
\hline \multicolumn{7}{|c|}{ Table A1: Non-migrant characteristics, by gender } \\
\hline & \multicolumn{2}{|c|}{ All } & \multicolumn{2}{|c|}{ Male } & \multicolumn{2}{|c|}{ Female } \\
\hline & Mean & $N$ & Mean & $N$ & Mean & $N$ \\
\hline Age & 26.15 & 6005 & 23.89 & 2902 & 28.27 & 3103 \\
\hline \multicolumn{7}{|l|}{ Education } \\
\hline None & 0.13 & 751 & 0.12 & 330 & 0.14 & 421 \\
\hline Primary & 0.49 & 2860 & 0.49 & 1388 & 0.48 & 1472 \\
\hline Middle & 0.30 & 1759 & 0.30 & 859 & 0.30 & 900 \\
\hline High & 0.03 & 149 & 0.03 & 90 & 0.02 & 59 \\
\hline Other & 0.06 & 365 & 0.06 & 176 & 0.06 & 189 \\
\hline Household size & 5.99 & 6016 & 6.04 & 2905 & 5.93 & 3111 \\
\hline Age of household head & 55.38 & 5786 & 55.58 & 2790 & 55.19 & 2996 \\
\hline Female household head & 0.33 & 1935 & 0.28 & 792 & 0.38 & 1143 \\
\hline \multicolumn{7}{|l|}{ Education of household head } \\
\hline None & 0.10 & 579 & 0.10 & 264 & 0.11 & $\begin{array}{c}315 \\
1410\end{array}$ \\
\hline Primary & 0.48 & 2715 & 0.47 & 1305 & 0.48 & $\begin{array}{l}1410 \\
1010\end{array}$ \\
\hline Middle & 0.35 & 1991 & 0.36 & 981 & 0.34 & 1010 \\
\hline High & 0.03 & 189 & 0.04 & 106 & 0.03 & 83 \\
\hline Other & 0.04 & 224 & 0.03 & 95 & 0.04 & 129 \\
\hline
\end{tabular}

\begin{tabular}{|c|c|c|c|c|c|c|}
\hline \multicolumn{7}{|c|}{ Table A2: Occupation of migrants at destination by sex of migrant } \\
\hline \multirow[b]{2}{*}{ Occupation } & \multicolumn{2}{|c|}{ Male } & \multicolumn{2}{|c|}{ Female } & \multicolumn{2}{|c|}{ Total } \\
\hline & $N$ & $\%$ & $N$ & $\%$ & $N$ & $\%$ \\
\hline $\begin{array}{l}\text { Technical/professional (eg } \\
\text { doctor/nurse/teacher/engineer) }\end{array}$ & 113 & 10.4 & 25 & 6 & 138 & 9.2 \\
\hline Manager & 6 & 0.6 & 0 & 0 & 6 & 0.4 \\
\hline Admin Staff & 25 & 2.3 & 8 & 1.9 & 33 & 2.2 \\
\hline sales worker (eg sales/waiter/ress) & 41 & 3.8 & 36 & 8.7 & 77 & 5.1 \\
\hline $\begin{array}{l}\text { service worker (eg office cleaner/security } \\
\text { guard/hotel worker) }\end{array}$ & 101 & 9.3 & 26 & 6.3 & 127 & 8.5 \\
\hline own farm & 2 & 0.2 & 1 & 0.2 & 3 & 0.2 \\
\hline paid labourer in agriculture & 50 & 4.6 & 19 & 4.6 & 69 & 4.6 \\
\hline transport operator & 50 & 4.6 & 2 & 0.5 & 52 & 3.5 \\
\hline skilled construction worker & 133 & 12.3 & 4 & 1 & 137 & 9.1 \\
\hline paid labourer (non-farm) & 101 & 9.3 & 16 & 3.9 & 117 & 7.8 \\
\hline production staff(textiles, electronics/other) & 26 & 2.4 & 7 & 1.7 & 33 & 2.2 \\
\hline own business (non-farm) & 47 & 4.3 & 14 & 3.4 & 61 & 4.1 \\
\hline domestic work & 6 & 0.6 & 79 & 19.0 & 85 & 5.7 \\
\hline in school/education & 15 & 1.4 & 17 & 4.1 & 32 & 2.1 \\
\hline unemployed and looking for job & 74 & 6.8 & 35 & 8.4 & 109 & 7.3 \\
\hline unemployed and not looking /retired & 14 & 1.3 & 22 & 5.3 & 36 & 2.4 \\
\hline Housewife & 4 & 0.4 & 34 & 8.2 & 38 & 2.5 \\
\hline others, specify & 2 & 0.2 & 0 & 0 & 2 & 0.1 \\
\hline Don't know & 268 & 24.7 & 61 & 14.7 & 329 & 21.9 \\
\hline Not applicable & 2 & 0.2 & 7 & 1.7 & 9 & 0.6 \\
\hline Total & 1,084 & 100 & 415 & 100 & 1,499 & 100 \\
\hline
\end{tabular}




\section{About the Migrating out of Poverty Research Programme Consortium}

Migrating out of Poverty is a research programme consortium (RPC) funded by the UK's Department for International Development (DFID). It focuses on the relationship between migration and poverty - especially migration within countries and regions - and is located in five regions across Asia and Africa. The main goal of Migrating out of Poverty is to provide robust evidence on the drivers and impacts of migration in order to contribute to improving policies affecting the lives and well-being of impoverished migrants, their communities and countries, through a programme of innovative research, capacity building and policy engagement. The RPC will also conduct analysis in order to understand the migration policy process in developing regions and will supplement the world renowned migration databases at the University of Sussex with data on internal migration.

The Migrating out of Poverty consortium is coordinated by the University of Sussex, and led by CEO Professor L. Alan Winters with Dr Priya Deshingkar as the Research Director. Core partners are: the Refugee and Migratory Movements Research Unit (RMMRU) in Bangladesh; the Centre for Migration Studies (CMS) at the University of Ghana; the Asia Research Institute (ARI) at the National University of Singapore; the African Centre for Migration \& Society (ACMS) at the University of the Witwatersrand in South Africa; and the African Migration and Development Policy Centre (AMADPOC) in Kenya.

Migrating out of Poverty

University of Sussex

Falmer, Brighton BN1 9QN, United Kingdom

tel: $+44(0) 1273873535$

email:migrationrpc@sussex.ac.uk

web: http://migratingoutofpoverty.dfid.gov.uk/

Twitter:@migrationrpc
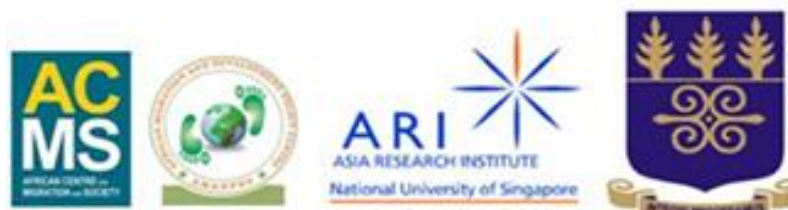